\title{
Long-term Results of Breast-conserving Surgery and Radiation Therapy in Early Breast Cancer
}

\author{
Jin Hee Kim, M.D., Ph.D., and Sang Jun Byun, M.D. \\ Department of Radiation Oncology, Dongsan Medical Center, Keimyung University \\ School of Medicine, Daegu, Korea
}

\begin{abstract}
Purpose: To evaluate the long-term results after breast-conserving surgery and radiation therapy in early breast cancer in terms of failure, survival, and cosmesis.

Materials and Methods: One hundred fifty-four patients with stage I and || breast cancer were treated with conservative surgery plus radiotherapy between January 1992 and December 2002 at the Keimyung University Dongsan Medical Center. According to TNM stage, 93 patients were stage I, 50 were Ila, and 11 were IIb. The affected breasts were irradiated with $6 \mathrm{MV}$ photons to 50.4 Gy in 28 fractions over 5.5 weeks with a boost irradiation dose of 10 16 Gy to the excision site. Chemotherapy was administered in 75 patients and hormonal therapy in 92 patients with tamoxifen. Follow-up periods were 13 179 months, with a median of 92.5 months. Results: The 5- and 10-year overall survival rates were $97.3 \%$ and $94.5 \%$, respectively. The 5- and 10-year disease-free survival (5YDFS and 10YDFS, respectively) rates were $92.5 \%$ and $88.9 \%$, respectively; the ultimate 5 YDFS and 10YDFS rates after salvage treatment were $93.9 \%$ and $90.2 \%$, respectively. Based on multivariate analysis, only the interval between surgery and radiation therapy ( $\leq 6$ weeks vs. $>6$ weeks, $p=0.017)$ was a statistically significant prognostic factor for DFS. The major type of treatment failure was distant failure $(78.5 \%)$ and the most common distant metastatic site was the lungs. The cosmetic results were good-to-excellent in 96 patients (80.7\%).

Conclusion: Conservative surgery and radiation for early stage invasive breast cancer yielded excellent survival and cosmetic results. Radiation therapy should be started as soon as possible after breast-conserving surgery in patients with early breast cancer, ideally within 6 weeks.
\end{abstract}

Key Words: Early breast cancer, Breast-conserving surgery, Radiation, Survival, Failure

\section{Introduction}

Breast conserving surgery combined with radiotherapy is a standard therapeutic procedure for patients with early breast cancer. Several phase III randomized trials have shown that survival after breast conserving treatment (BCT) consisting of local excision and whole breast irradiation was equal to the survival rate after radical mastectomy. ${ }^{1 \sim 3)}$ In 1992, the Journal of National Cancer Institute published a monograph stating that breast conservation treatment is an appropriate method of

Submitted August 25, 2009, accepted September 9, 2009

Reprint requests to Jin Hee Kim, Department of Radiation Oncology, Dongsan Medical Center, Keimyung University School of Medicine, 194, Dongsan-dong, Jung-gu, Daegu 700-712, Korea Tel: 053)250-7665, Fax: 053)250-7984

E-mail: jhkim@dsmc.or.kr primary therapy for most women with stage I or II breast cancer. ${ }^{4)}$ According to a 2002 annual report of the Korean Central Registry, breast cancer is the most common cancer of women and comprises $16.8 \%$ of all reported cancers in Korea. ${ }^{5)}$ In Korea, the incidence of early stage breast cancer is increasing with the use of screening mammography. The proportion of breast conserving treatment is also increasing with $18.7 \%$ in $1996,27 \%$ in 2000 and $41.9 \%$ in $2004 .{ }^{6}$ ) Our institution started team approach for breast conservation treatment in early breast cancer in 1992. We have previously reported preliminary results of breast conserving treatment in early breast cancer. ${ }^{7)}$ We here report long term results of our experiences in terms of survival, prognostic factors, failure, and cosmetic results. 


\section{Materials and Methods}

From January 1992 through December 2002, one hundred fifty four patients with early stage I and II breast cancer were treated with breast conserving surgery and radiotherapy at Keimyung University Dongsan Medical Center. Patient characteristics are presented in Table 1. Age distribution was 25 to 72 years old with median age of 44 . According to TNM stage, ninety three patients were stage I, fifty were IIa, and eleven were IIb. There were 122 patients of N0, 26 of N1 (1 $\sim 3)$ and 6 of $N 2(\geq 4)$. The most common pathology was invasive ductal carcinoma with one hundred twenty two patients $(79.2 \%)$. In ninety patients (58.4\%), the lesions were located in the left breast. The most common site was upper outer quadrant (UOQ, 92 patients) followed by upper inner quadrant (UIQ, 32), lower outer quadrant (LOQ, 14), lower inner quadrant (LIQ, 8), and central area (8).

All patients underwent excision of all gross tumors in the procedure that attempted to achieve histologically negative surgical margins. Several patients were referred from local surgeons after biopsy and we performed removal of the most of tumor as much as possible. In these patients, re-excisions were performed when feasible if surgical margins were involved or if they could not be assessed. One patient with positive surgical resection margin didn't receive re-excision. In addition, all but 7 patients underwent level I-II axillary lymph node dissection for staging. Median number of dissected node was 20 (Table 2). In some cases, radio-opaque hemoclips were placed at the margin of resection to assist the radiation oncologist in treatment planning of boost fields to the tumor bed. Radiation therapy was performed at $1.5 \sim 32.8$ weeks (median, 3.6 weeks) after surgery. All patients had ipsilateral breast treated with radiation. Radiation therapy to ipsilateral breast was delivered through medial and lateral tangential fields of $6 \mathrm{MV}$ photons to $50.4 \mathrm{~Gy}$ in 28 fractions over 5.5 weeks. Medial margin was $1 \mathrm{~cm}$ over the midline of anterior chest. Upper margin of the portals was placed at the head of the clavicle to include the entire breast. Lateral margin was placed $2 \mathrm{~cm}$ beyond all palpable breast tissue, which is usually near the mid-axillary line. Inferior margin was drawn $1 \mathrm{~cm}$ below the inframammary fold. Compensating wedge filter was used to whole breast irradiation in most patients.
Table 1. Patient Characteristics

\begin{tabular}{|c|c|c|}
\hline \multicolumn{2}{|c|}{ Characteristics } & \multirow{3}{*}{$\begin{array}{c}\text { No. of patients } \\
42 \\
112\end{array}$} \\
\hline Age (yr) & $<40$ & \\
\hline & $\geq 40$ & \\
\hline \multirow[t]{6}{*}{ Pathology } & Invasive ductal carcinoma & 122 \\
\hline & Mucinous carcinoma & 9 \\
\hline & Papillary carcinoma & 5 \\
\hline & Medullary carcinoma & 6 \\
\hline & Tubular carcinoma & 3 \\
\hline & Other & 9 \\
\hline \multirow[t]{5}{*}{ T-stage } & T1a & 3 \\
\hline & T1b & 23 \\
\hline & T1c & 90 \\
\hline & T2 & 37 \\
\hline & $\mathrm{T} 3$ & 1 \\
\hline \multirow[t]{3}{*}{ N-stage } & No & 122 \\
\hline & N1 (1 3) & 26 \\
\hline & $\mathrm{N} 2(\geq 4)$ & 6 \\
\hline \multirow[t]{3}{*}{ Stage } & I & 93 \\
\hline & IIa & 50 \\
\hline & $\mathrm{IIb}$ & 11 \\
\hline \multirow[t]{4}{*}{ Resection margin } & - & 131 \\
\hline & + & 1 \\
\hline & Close & 9 \\
\hline & Unknown & 13 \\
\hline \multirow[t]{3}{*}{ ER } & - & 44 \\
\hline & + & 48 \\
\hline & Unknown & 62 \\
\hline \multirow[t]{3}{*}{ PR } & - & 44 \\
\hline & + & 47 \\
\hline & Unknown & 63 \\
\hline \multirow[t]{2}{*}{ Site } & Left & 90 \\
\hline & Right & 64 \\
\hline \multirow[t]{5}{*}{ Location } & $\mathrm{UOQ}^{*}$ & 92 \\
\hline & $\mathrm{UIQ}_{\neq}^{\dagger}$ & 32 \\
\hline & $\mathrm{LOQ}^{\ddagger}$ & 14 \\
\hline & $\mathrm{LIQ}^{\S}$ & 8 \\
\hline & Central & 8 \\
\hline Total & & 154 \\
\hline
\end{tabular}

*upper outer quadrant, ${ }^{\dagger}$ upper inner quadrant, ${ }^{\dagger}$ lowerouter quadrant, ${ }^{\S}$ lower inner quadrant

Margins, in general, were $2 \sim 3 \mathrm{~cm}$ from the scar, depending on the size of the lesion and the adequacy of the surgical margins. A boost of $10 \mathrm{~Gy}$ in 5 days was delivered through reduced fields with electrons of appropriate energy $(6 \sim 12 \mathrm{MeV})$. If the margins contained tumor or if the status of the margins were close or unknown, electron beam boost was escalated to deliver $16 \mathrm{~Gy}$. In fourteen patients with axillary node involve- 
Table 2. Treatment

\begin{tabular}{|c|c|c|c|c|}
\hline \multicolumn{2}{|c|}{ Surgery } & No. & Radiation therapy & Dose (Gy) \\
\hline \multicolumn{2}{|l|}{ Wide excision } & 147 & Ipsilateral breast & $45 \sim 50.4($ median 50.4$)$ \\
\hline \multicolumn{2}{|c|}{ Axillary LN dissection } & 140 & Tumor bed boost & 10 16 (median 10) \\
\hline \multicolumn{2}{|c|}{ Sentinel LN biopsy } & 7 & Supraclavicular LN $^{\S}$ & $45 \sim 50.4$ (median 50) \\
\hline \multicolumn{2}{|c|}{ Chemotherapy } & No. & Hormonal therapy" & No. \\
\hline Yes & & 75 & Yes & 92 \\
\hline \multirow[t]{4}{*}{ Regimen: } & $\mathrm{CMF}^{*}$ & 58 & No & 62 \\
\hline & $\mathrm{AC}^{\dagger}$ & 9 & & \\
\hline & $\mathrm{FEC}^{\ddagger}$ & 6 & & \\
\hline & AC-Taxol & 2 & & \\
\hline No & & 79 & & \\
\hline
\end{tabular}

${ }^{*}$ cyclophosphamide + methotrexate +5 -fluorouracil,${ }^{\dagger}$ adriamycin + cyclophosphamide, ${ }^{\dagger} 5$-FU + epirubicin + cyclophosphamide, ${ }^{\S} 18$ patients among $\mathrm{N}(+), "$ tamoxifen

ment, ipsilateral supraclavicular node and level III axillary node was treated up to 45 to 50 Gy over five weeks. Adjuvant chemotherapy was administered in seventy five patients with several regimens such as CMF (cyclophosphamide, methotrexate, 5-fluorouracil), AC (adriamycin ${ }^{\circledR}$, cyclophosphamide), FEC (5-FU, epirubicin, cyclophosphamide). Adjuvant hormonal therapy was administered in ninety two patients with tamoxifen.

Cosmetic results were assessed by questionnaire to patients grading from excellent, good, fair to poor.

Follow-up period was 13 to 179 months with median 92.5 months. The time to local failure and distant metastases were analyzed from primary surgery. Five year- and ten yeardisease free survival rate (5YDFS, 10YDFS) were also evaluated from the day of surgery. We used Kaplan-Meier method for overall and disease free survival, log-rank test for prognostic significance, and Cox-proportional hazard model for multivariate analysis. We used p-value below 0.05 which was statistically significant. We also used Pearson correlation coefficient to analyze the relation between factors which were statistically significant by univariate analysis.

\section{Results}

\section{Survival rates and prognostic factors}

Five year- and ten year-overall survival rate (5YOS, 10YOS) were $97.3 \%$ and $94.5 \%$ (Fig. 1). 5YDFS, 10YDFS were $92.5 \%$ and $88.9 \%$ (Fig. 1). After salvage treatment, ultimate 5YDFS and 10YDFS were 93.9\% and 90.2\%. To

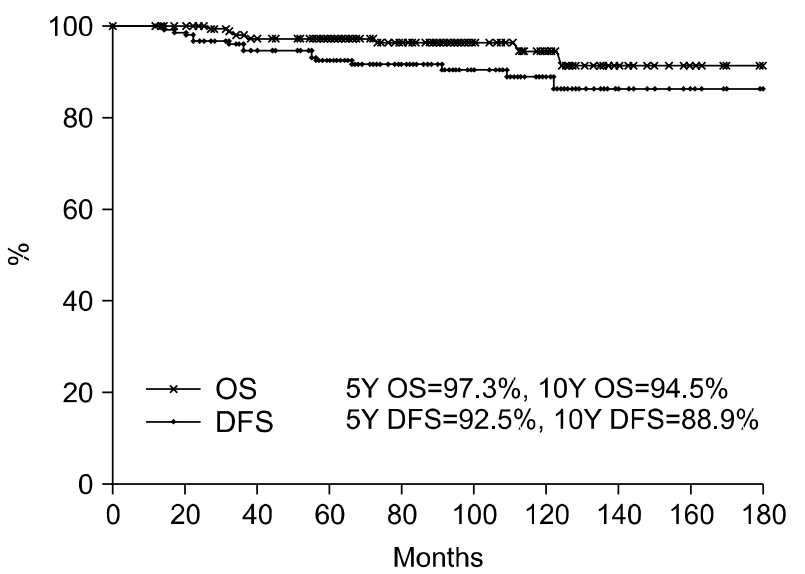

Fig. 1. Overall survival (OS) curve \& disease free survival (DFS) curve.

evaluate prognostic factors affecting overall and disease free survival, we analyzed prognostic factors such as age, surgical margin, estrogen receptor, progesterone receptor, stage including $\mathrm{T}$-stage and $\mathrm{N}$-stage, hormonal therapy, chemotherapy and interval between surgery and radiation therapy. There was no statistically significant prognostic factor for overall survival by univariate analysis. $\mathrm{N}$-stage, chemotherapy and interval between surgery and radiation therapy were statistically significant prognostic factors affecting disease free survival by univariate analysis (Table 3). There were statistically significant differences in disease free survival by interval between surgery and radiation therapy (5YDFS $96.7 \%$ vs. 76.7\%, 10YDFS $93.1 \%$ vs. $63.6 \%, \leq 6$ weeks vs. $>6$ weeks, $\mathrm{p}=0.000$ )(Fig. 2), $\mathrm{N}$-stage (5YDFS 94.1\%，87.8\%，83.3\%， 10YDFS 92\%, $77.65 \%, 0 \%$ in N0, N1, N2 respectively, p=0.047)(Fig. 3), and 
Table 3. Univariate Analysis of Prognostic Factors for Disease-free Survival

\begin{tabular}{|c|c|c|c|}
\hline Factors & & 5YDFS* & $\mathrm{p}$-value \\
\hline \multirow[t]{2}{*}{ Age } & $<40$ & 85.7 & 0.42 \\
\hline & $\geq 40$ & 93.7 & \\
\hline \multirow[t]{3}{*}{ Surgical margin } & Close/positive & 100 & 0.56 \\
\hline & Negative & 92.9 & \\
\hline & Unknown & 84.6 & \\
\hline \multirow{3}{*}{ Estrogen receptor } & Positive & 95.3 & 0.61 \\
\hline & Negative & 90.9 & \\
\hline & Unknown & 91.7 & \\
\hline \multirow[t]{3}{*}{ Progesterone receptor } & Positive & 93.1 & 0.30 \\
\hline & Negative & 90.6 & \\
\hline & Unknown & 93.6 & \\
\hline \multirow{5}{*}{ T-stage } & T1a & 100 & 0.82 \\
\hline & $\mathrm{T} 1 \mathrm{~b}$ & 94.1 & \\
\hline & T1c & 89.7 & \\
\hline & $\mathrm{T} 2$ & 94.3 & \\
\hline & $\mathrm{T} 3$ & 100 & \\
\hline \multirow[t]{3}{*}{ N-stage } & N0 & 94.1 & 0.047 \\
\hline & N1 & 87.8 & \\
\hline & N2 & 83.3 & \\
\hline \multirow[t]{2}{*}{ Hormonal therapy } & Yes & 93.1 & 0.33 \\
\hline & No & 92.2 & \\
\hline \multirow[t]{2}{*}{ Chemotherapy } & Yes & 87.4 & 0.026 \\
\hline & No & 97.4 & \\
\hline \multirow{2}{*}{$\begin{array}{l}\text { Interval between surgery } \\
\text { and radiation therapy }\end{array}$} & $\leq 6 \mathrm{wk}$ & 96.7 & 0.000 \\
\hline & $>6 \mathrm{wk}$ & 76.7 & \\
\hline
\end{tabular}

*5 yr disease-free surviral

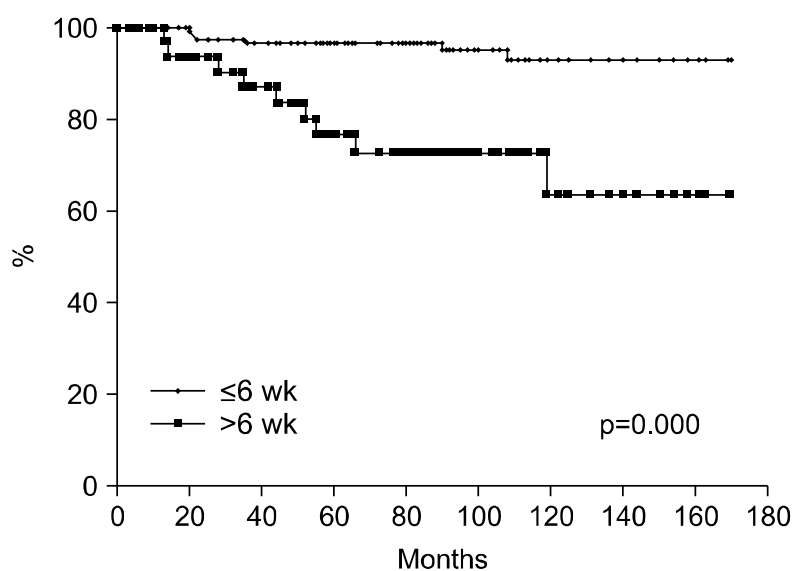

Fig. 2. Disease free survival curve by the interval between surgery and radiotherapy.

chemotherapy (5YDFS $87.4 \%$ vs. 97.4\%, 10YDFS $85.5 \%$ vs. $92.8 \%$, with chemotherapy vs. without chemotherapy, $\mathrm{p}=0.026$ ) (Fig. 4). According to stage, 5YDFS and 10YDFS was 93.3\% and $90.6 \%, 91.7 \%$ and $89 \%, 90 \%$ and $75 \%$ in stage I, IIa and IIb (Fig. 5), respectively. By multivariate analysis of chemotherapy, $\mathrm{N}$-stage and the interval between surgery and radia-

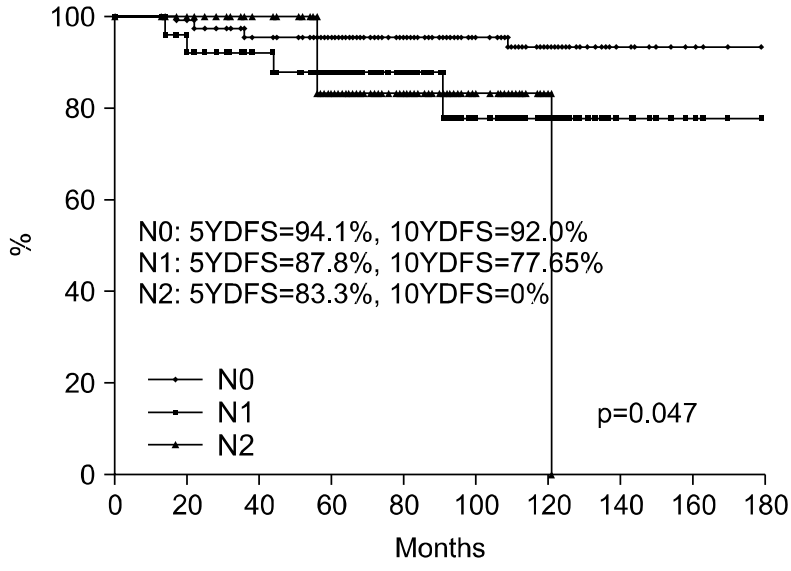

Fig. 3. Disease free survival (DFS) curve by N-stage.

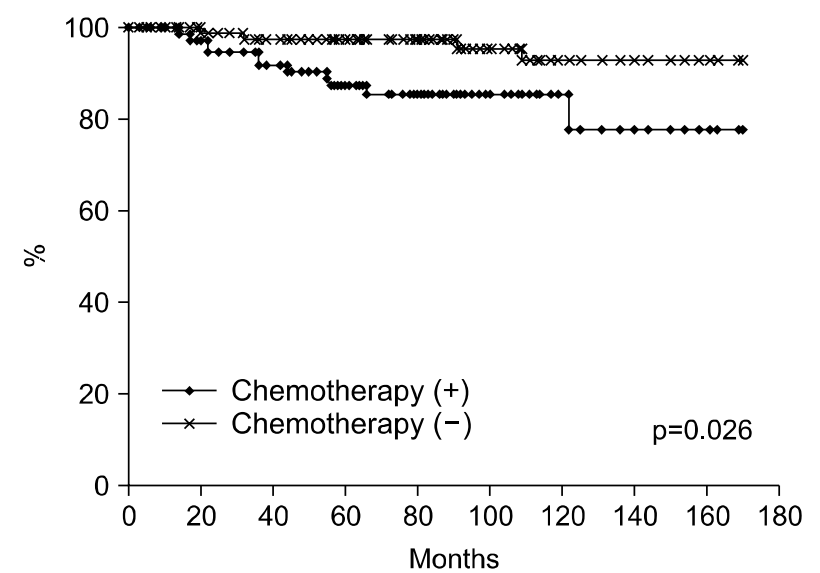

Fig. 4. Disease free survival curve by chemotherapy.

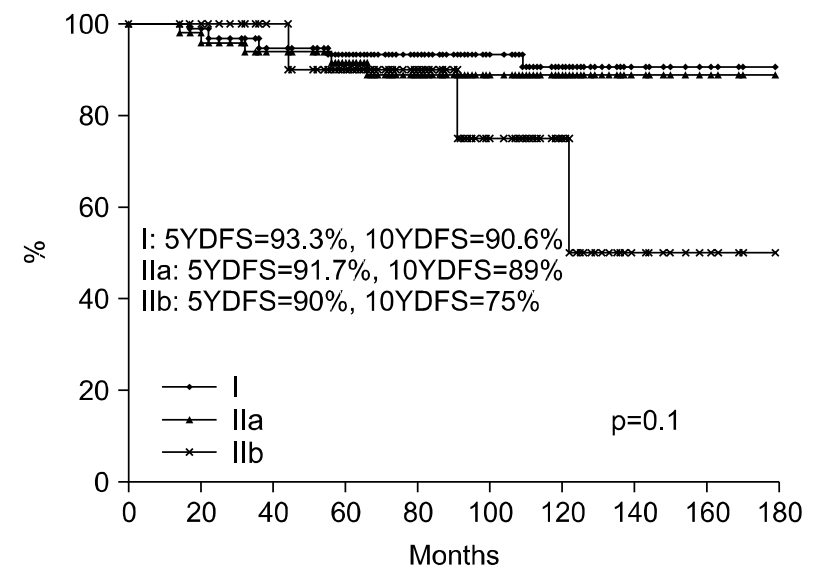

Fig. 5. Disease free survival (DFS) curve by stage.

tion therapy which were statistically significant in univariate analysis, only the interval between surgery and radiation therapy was a significant prognostic factor for disease free 
survival ( $\leq 6$ weeks vs. $>6$ weeks; HR, $0.21 ; 95 \%$ CI, 0.058 to $0.756 ; \mathrm{p}=0.017)$. There was strong correlation between $\mathrm{N}$-stage and interval between surgery and radiation therapy (Pearson correlation coefficient $=0.513$ ).

\section{Patterns of failure}

Fourteen patients out of one hundred fifty four had treatment failure $(9.1 \%)$. Ten patients had distant metastasis and one had local and distant failure and three had ipsilateral local failure. Local failure developed after 17, 22 and 50 months and they were treated by surgery, chemotherapy and hormonal therapy. One of them had tumor bed relapse and the rest two had local failure in elsewhere. The patient with tumor bed recurrence was salvaged by wide excision and hormonal therapy so one of three with local recurrence has conserved the breast after salvage treatment. The major type of failure was distant failure (78.5\%) and most patients with distant metastasis had multiple metastatic sites with 55.5 months of median time. The most common distant metastatic site was

Table 4. Patterns of Failure

\begin{tabular}{lc}
\hline \multicolumn{1}{c}{ Type of failure } & No. (\%) \\
\hline Distant metastasis* & $10 / 14(71.4)$ \\
Local failure alone & $3 / 14(21.4)$ \\
Local failure \& distant metastasis & $1 / 14(7.1)$ \\
\hline
\end{tabular}

*median time to distant metastasis: 55.5 months lung. Patients with distant metastasis received chemotherapy, supportive care or surgery (Table 4). The status of patients with treatment failure is presented in Table 5.

\section{Complication and cosmesis}

Four patients $(2.5 \%)$ had an arm edema more than NCI CTCAE grade II with 57 months of median time. They had radiation therapy to only ipsilateral breast and mean numbers of dissected axillary lymph node were 11.5. One of them had local failure and received total mastectomy. One patient had doxorubicin induced cardiac failure. She had recurrent tumor in left breast 44 months after primary treatment. She underwent neoadjuvant chemotherapy with doxorubicin containing regimen and total mastectomy. She died from doxorubicin induced cardiac failure 59 months after the primary treatment (Table 6). One hundred nineteen patients answered our cosmetic result questionnaire and the results were good to excellent in ninety six patients $(80.7 \%)$ (Fig. 6). There was no significant effect of tumor location and tumor size to cosmesis.

Table 6. Complications

\begin{tabular}{lc}
\hline \hline & No. (\%) \\
\hline Arm edema* $^{*}$ & $4(2.5)$ \\
Adriamycin induced cardiac failure $^{\dagger}$ & $1(0.6)$ \\
\hline${ }^{*}$ median time to radiation: 57 months, ${ }^{\dagger}$ recurrent breast cancer \\
(patient 13 in Table 5)
\end{tabular}

Table 5. Status of Failed Patient

\begin{tabular}{clllc}
\hline \hline Patient & Initial stage & \multicolumn{1}{c}{ Failure (months) } & Treatment after failure & Status (months) \\
\hline 1 & T2 N2 M0 & Lung, Bone, SCL* (122) & CHT $^{\dagger}$ & DOD $^{\ddagger}(127)$ \\
2 & T1c N1 M0 & Lung, SCL (20) & Supportive care & DOD (32) \\
3 & T2 N2 M0 & Bone (91), SCL (144) & CHT, Excision & DOD (137) \\
4 & T1c N0 M0 & Lung, Liver, SCL (109) & CHT & DOD (130) \\
5 & T1c N1 M0 & Lung (55), Bone (76) & CHT & DOD (73) \\
6 & T1b N1 M0 & Lung (66) & CHT & DOD (88) \\
7 & T1c N2 M0 & Liver, Ovary, Kidney (56) & CHT & DOD (87) \\
8 & T1c N0 & Lung (36) & CHT & DOD (53) \\
9 & T1c N0 & Lung (36), Bone (40) & HOD & DOD (38) \\
\hline 10 & T2 N0 M0 & Liver (32) & TM ${ }^{\sharp}$, CHT & DOD (34) \\
\hline 11 & T1c N1 M0 & Breast (14), Lung (19) & TM, CHT, HRT & NED $(81)$ \\
12 & T1c N0 M0 & Breast (22) & TM, CHT & DI* (59) \\
14 & T2 N1 M0 & Breast (50) & Wide excision, HRT & NED (95) \\
\hline
\end{tabular}

*supraclavicular lymph node, ${ }^{\dagger}$ chemotherapy, ${ }^{\dagger}$ dead of disease, ${ }^{\S}$ total mastectomy, ${ }^{\S}$ hormone therapy, "total mastectomy, "no evidence of disease, $* *$ die of intercurrent disease (adriamycin induced cardiac failure) 


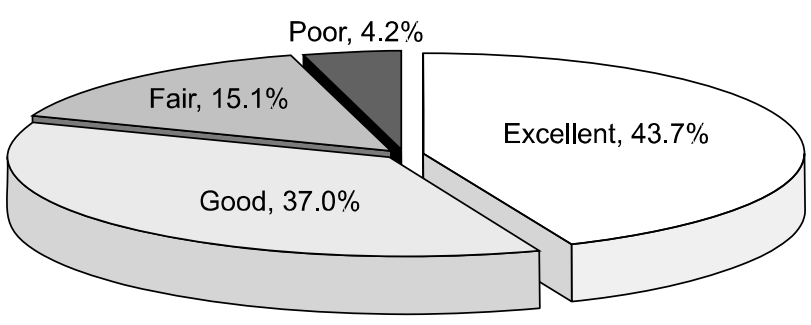

Fig. 6. Cosmetic results.

\section{Discussion and Conclusion}

Over the past two decades, we knew that mastectomy is not needed for most small tumors and does not improve prognosis for more extensive disease. Therefore, as many as $80 \%$ of the patients with invasive breast cancer may benefit from breast conserving treatment (BCT), offering good cosmesis and identical disease control and survival compared to modified radical mastectomy. The number of patients suitable for BCT might even further increase as patients are now diagnosed at earlier stage. This trend is reinforced through the implementation of mass screening for breast cancer. ${ }^{8)}$ In the USA, $58 \%$ of patients with stage I breast cancer and $36.2 \%$ of patients with stage II breast cancer underwent BCS according to one report. ${ }^{9)}$ In our institute, we have performed breast conserving treatment in early breast cancer since 1992. Our results of 5YOS and 10YOS in early breast cancer were $97.3 \%$ and 95.8\%. 5YDFS and 10YDFS were $92.5 \%$ and $88.9 \%$ and ultimate 5YDFS and 10YDFS were 93.9\% and 90.2\%. These results were compatible to other nonrandomized studies. ${ }^{10 \sim 16)}$ Chie et al. $^{14)}$ reported that five year overall survival and disease free survival after breast conserving treatment in breast cancer were $93.1 \%$ and $88.7 \%$. Kim et al. ${ }^{15)}$ also reported that the 5YOS and 5YDFS after breast conserving treatment in early breast cancer were 95.3 and $88.5 \%{ }^{16}$ )

Recently many randomized studies reported long term results. $^{2,17 \sim 21)}$ Researchers have shown that local failure rates were in the range of $3 \sim 22 \%$. However local failure rates were about $10 \%$ excluding two studies with high local failure rate. $^{1920)}$ In our study, the local relapse occurred in five patients $(3.2 \%)$. This is very low compared with other studies and comparable to randomized study of Danish Breast Cancer Cooperative Group. ${ }^{21)}$ Our study shows that main failure pattern was distant metastasis. In early stage breast cancer, distant metastasis was more frequent than local failure, which means there was micro-metastasis developed in early stage. Therefore, we believe that the more effective combined chemotherapy is needed to improve survival in high risk group.

There were so many prognostic factors affecting overall survival and disease free survival. Some researchers have reported that patients with positive surgical margin had high local failure. ${ }^{22 \sim 25)}$ In this study, eight patients had close resection margin, whereas one patient had positive resection margin. However we didn't have statistically significant difference by margin status. We believe this was due to small number of patients with close or positive margin.

Young age $(<35$ or 40 years) has been associated with an increased risk of breast recurrence in a number of series. ${ }^{26,27)}$ In our study, age was not prognostic factor affecting survival. The proportion of young patients $(<40$ years) was $27.2 \%$ and higher than that of American series, which was 7\%. ${ }^{27)}$ Therefore, we should make an effort to improve treatment results in young patients. $\mathrm{N}$-stage, chemotherapy and interval between surgery and radiation therapy were statistically significant prognostic factors affecting disease free survival by univariate analysis in this study. Patients who received chemotherapy had inferior disease free survival compared to those who did not. After multivariate analysis, the statistical significance of chemotherapy was not shown. This means that patients with more advanced disease received chemotherapy. Only the interval between surgery and radiation therapy was a statistically significant prognostic factor by multivariate analysis. Clinical trials and clinical practice guidelines have variously recommended that intervals between breast conserving surgery (BCS) and radiation therapy (RT) should be less than 6 weeks to less than 16 weeks. The available meta-analyses of the effect of BCS-to-RT intervals on breast cancer outcomes have yielded disparate results. Olivotto et al. ${ }^{28)}$ showed that intervals longer than 20 weeks from BCS-to-RT are associated with inferior outcome for women with early-stage breast cancer who are not receiving chemotherapy. But they had improved local control compared with no RT at all (HR, 2.32; p=0.08). They suggested that RT should not be withheld, even if the elapsed time from surgery is greater than 20 weeks. Also Huang et al. $^{29)}$ found that BCS-to-RT intervals of 8 weeks and longer were associated with a higher risk of local recurrence (odds ratio, $1.62 ; 95 \% \mathrm{CI}, 1.20$ to 2.16 ) but with no significant 
difference in distant recurrence or breast cancer death. Chen et al. $^{30)}$ found an increased risk of local recurrence (relative risk, 1.11 per month of delay; $95 \% \mathrm{CI}, 0.94$ to 1.33 ) but found no difference in distant recurrence or survival with longer BCSto-RT intervals. In contrast, Hebert-Croteau et al. ${ }^{31)}$ reported no significant associations between the BCS-to-RT interval and local recurrence or breast cancer death. Therefore, we considered that radiation therapy need to be started after breast conserving surgery as soon as reasonably achievable, especially within 6 weeks according to our results.

There were four patients with arm swelling more than NCI CTCAE grade II. Powell et al. ${ }^{32)}$ have shown that nodal irradiation was the only significant risk factor for arm lymphedema in patients receiving breast conservation therapy for early-stage breast cancer in meta-analysis. Bar $\mathrm{Ad}$ et al. ${ }^{33)}$ suggested that mild arm lymphedema, generally considered to be a minor complication after breast conservation treatment for breast cancer, was associated with a risk of progression to a more severe grade of arm lymphedema in a substantial fraction of patients. Therefore we should pay attention to mild arm edema in breast cancer patients.

We experienced doxorubicin induced cardiac failure. She had a stage IIb left breast cancer. She received breast conserving treatment with six cycles of CMF chemotherapy and recurred at left breast after 44 months. She underwent neoadjuvant doxorubicin containing chemotherapy and total mastectomy. She died of doxorubicin induced cardiac failure 59 months after primary treatment. We believe that physician should be careful in treating patients with doxorubicin containing chemotherapy for patients with left breast cancer with previous medical history of radiation and chemotherapy.

Cosmetic results were reported as good or excellent in more than 80 percent in MD Anderson report but good in 50 percents in European report. ${ }^{34)}$ Other series reported excellent cosmetic results of $86 \%$ and good to excellent of $93 \%$, which were usually physician assessment cosmetic score. ${ }^{35,36)}$ Arenas et al. ${ }^{37)}$ have shown that $73 \%$ of patients rated cosmesis as excellent or good, while the percentage was $71 \%$ when rated by radiation oncologists. Our cosmetic result was patient's opinion. Our patients had a good to excellent cosmetic result in $80.7 \%$.

Breast conserving treatments in early breast cancer was excellent in local control and survival. It takes about 6 weeks for radiation therapy and patients may have difficulty to reach hospital if it is far from their residential area. ${ }^{38)}$ Therefore many attempt have been made to identify subgroups of patients who might avoid radiation therapy after breast conserving surgery in early breast cancer. However, Veronesi et al. ${ }^{39)}$ reported that local recurrence was significantly higher in patients treated with surgery alone (59 cases out of 273; 10 -year crude cumulative incidence of $23.5 \%$ ) than in patients treated with surgery plus radiotherapy (16 cases out of 294; 10-year crude cumulative incidence of $5.8 \%$ ) in spite of quadrantectomy in small breast cancer. Radiation therapy may not be necessary after conservative surgery in selected elderly patients (over 70 years) with small endocrine responsive cancer whose tumor excision was complete and who receive tamoxifen, although long-term follow up is not yet available. ${ }^{40)}$ Recently, accelerated partial breast irradiation (APBI) to reduce the treatment period has been investigated for patients with early stage breast cancer who are expected to have a good prognosis. ${ }^{41)}$ The results of APBI are consistent and successful, but selecting patients who are appropriate for APBI is very difficult and controversial.

In conclusion, ten year-overall survival rate was $95.8 \%$, ten year- disease free survival rate was $88.9 \%$ after receiving breast conserving treatment in early breast cancer at Keimyung University Dongsan hospital. After salvage treatment, ultimate ten year disease free survival rate was $90.2 \%$. Only the interval between surgery and radiation therapy was a statistically significant prognostic factor affecting disease free survival in multivariate analysis. We have shown that breast conservative operation and radiation therapy for early stage invasive breast cancer have excellent local control, survival and cosmetic results. We also considered that radiation therapy need to be started after breast conserving surgery as soon as reasonably achievable, especially within 6 weeks according to our results.

\section{Acknowledgments}

We appreciate Yoo Sa Kim M.D., Ph.D. who retired from Keimyung University Dongsan Hospital, School of Medicine at February 2006 for devoted contributions on breast conserving treatment of breast cancer. 


\section{References}

1. Fisher B, Bauer M, Margolese R, et al. Five year result of a randomized clinical trial comparing total mastectomy and segmental mastectomy with or without radiation in the treatment of breast cancer. N Engl J Med 1985;312:665-673

2. Sarrazin D, Le MG, Arriagada R, et al. Ten-year results of a randomized trial comparing a conservative treatment to mastectomy in early breast cancer. Radiother Oncol 1989;14: 177-184

3. Veronesi U, Salvadori B, Luini A, et al. Breast conservation is a safe methods in patients with small cancer of the breast long-term results of three randomized trials on 1,973 patients. Eur J Cancer 1995;31A:1574-1579

4. National Institutes of Health Consensus Development Panel. Consensus statement: treatment of early-stage breast cancer. J Natl Cancer Inst Monogr 1992;11:1-5

5. National Cancer Center. Cancer Prevalence Statistics: 23rd Korean Central Registry Report. Goyang; National Cancer Center, 2002

6. Ahn SH, Yoo KY. The breast cancer society: chronological changes of clinical characteristics in 31115 new breast cancer patients among Koreans during 1996 2004. Breast Cancer Res Treat 2006;99:209-214

7. Kim JH, Kim OB, Kim YS. Breast conserving operation and radiation therapy in early breast cancer: interim analysis. $\mathrm{J}$ Korean Soc Ther Radiol Oncol 2001;19:27-33

8. Bland KI, Menck HR, Scott-Conner CE, Morrow M, Winchester DJ, Winchester DP. The National Cancer Data Base 10-year survey of breast carcinoma treatment at hospitals in the United States. Cancer 1998:83:1262-1273

9. Dubois JB, Gary-Bobo J, Pourquier H, et al. Tumorectomy and radiotherapy in early breast cancer: a report on 392 patients. Int J Radiat Oncol Biol Phys 1988;15:1275-1282

10. Fowble B, Solin LJ, Schultz DJ, et al. Breast recurrence following conservative surgery and radiation: patterns of failure, prognosis, and pathologic findings from mastectomy specimens with implications for treatment. Int $\mathrm{J}$ Radiat Oncol Biol Phys 1990;19:833-842

11. Kurtz JM, Amalric R, Brandone $\mathrm{H}$, et al. Local recurrence after breast-conserving surgery and radiotherapy: frequency, time course, and prognosis. Cancer 1989;63:19121917

12. Pierquin B, Huart J, Raynal M, et al. Conservative treatment for breast cancer: long-term results (15 years). Radiother Oncol 1991;20:16-23

13. Solin LJ, Fowble B, Martz KL, et al. Definitive irradiation for early stage breast cancer: the University of Pennsylvania experience. Int J Radiat Oncol Biol Phys 1988;14:235-242

14. Chie EK, Kim K, Choi JH, et al. Results of breast conserving surgery and subsequent postoperative radiotherapy for cases of breast cancer. J Korean Soc Ther Radiol Oncol
2008:26:142-148

15. Kim KJ, Huh SJ, Yang JH, et al. Treatment results and prognostic factors of early breast cancer treated with a breast conserving operation and radiotherapy. Jpn J Clin Oncol 2005; 35:126-133

16. Fisher B, Anderson S, Bryant J, et al. Twenty-year follow-up of a randomized trial comparing total mastectomy, lumpectomy, and lumpectomy plus irradiation for the treatment of invasive breast cancer. N Engl J Med 2002;347:1233-1241

17. Veronesi U, Cascinelli N, Mariani L, et al. Twenty-year follow-up of a randomized study comparing breast-conserving surgery with radical mastectomy for early breast cancer. $\mathrm{N}$ Engl J Med 2002;347:1227-1232

18. Poggi MM, Danforth DN, Sciuto LC, et al. Eighteen-year results in the treatment of early breast carcinoma with mastectomy versus breast conservation therapy: the National Cancer Institute Randomized Trial. Cancer 2003;98:697-702

19. Van Dongen JA, Voogd AC, Fentiman IS, et al. Longterm results of a randomized trial comparing breast-conserving therapy with mastectomy: European Organization for Research and Treatment of Cancer 10801 trial. J Natl Cancer Inst 2000; 92:1143-1145

20. Blichert-Toft M, Rose C, Andersen JA, et al. Danish randomized trial comparing breast conservation therapy with mastectomy: six years of life-table analysis. Danish Breast Cancer Cooperative Group. J Natl Cancer Inst Monogr 1992; 11:19-25

21. Veronesi U, Volterrani F, Luini A, et al. Quadrantectomy vs. lumpectomy for small size breast cancer. Eur J Cancer 1990;26:671-673

22. Park CC, Mitsumori M, Nixon A, et al. Outcome at 8 years after breast-conserving surgery and radiation therapy for invasive breast cancer: influence of margin status and systemic therapy on local recurrence. J Clin Oncol 2000;18:1668-1675

23. Freedman G, Fowble B, Hanlon A, et al. Patients with early stage invasive cancer with close or positive margins treated with conservative surgery and radiation have an increased risk of breast recurrence that is delayed by adjuvant systemic therapy. Int J Radiat Oncol Biol Phys 1999;44:10051015

24. Leong C, Boyages J, Jayasinghe UW, et al. Effect of margins on ipsilateral breast tumor recurrence after breast conservation therapy for lymph node-negative breast carcinoma. Cancer 2004;100:1823-1832

25. Fowble BL, Schultz DJ, Overmoyer B, et al. The influence of young age on outcome in early stage breast cancer. Int J Radiat Oncol Biol Phys 1994;30:23-33

26. Zhou P, Reht A. Young age and outcome for women with early stage invasive breast carcinoma. Cancer 2004;101:12641274

27. Hankey BF, Miller B, Curtis R, Kosary C. Trends in breast cancer in younger women in contrast to older women. $J$ Natl cancer Inst Monogr 1994;16:7-14

28. Olivotto IA, Lesperance ML, Truong PT, et al. Intervals 
longer than 20 weeks from breast-conserving surgery to radiation therapy are associated with inferior outcome for women with early-stage breast cancer who are not receiving chemotherapy. J Clin Oncol 2009;27:16-23

29. Huang J, Barbera L, Brouwers M, et al. Does delay in starting treatment affect the outcomes of radiotherapy? A systematic review. J Clin Oncol 2003;21:555-563

30. Chen Z, King W, Pearcey R, et al. The relationship between waiting time for radiotherapy and clinical outcomes: a systematic review of the literature. Radiother Oncol 2008; 87:3-16

31. Hébert-Croteau N, Freeman CR, Latreille J, et al. Delay in adjuvant radiation treatment and outcomes of breast cancer: a review. Breast Cancer Res Treat 2002;74:77-94

32. Powell SN, Taghian AG, Kachnic LA, Coen JJ, Assaad S. Risk of lymphedema after regional nodal irradiation with breast conservation therapy. Int J Radiat Oncol Biol Phys 2003; 55:1209-1215

33. Bar Ad V, Cheville A, Solin LJ, Dutta P, Both S, Harris EE. Time course of mild arm lymphedema after breast conservation treatment for early-stage breast cancer. Int $\mathrm{J}$ Radiat Oncol Biol Phys Epub 2009 May 8

34. Dewar JA, Benhamou S, Benhamou E, et al. Cosmetic results following lumpectomy, axillary dissection and radiotherapy for small breast cancer. Radiother Oncol 1988;12:273-280
35. Beadle GF, Silver B, Botnick L, Hellman S, Harris JR. Cosmetic results following primary radiation therapy for early breast cancer. Cancer 1984;54:2911-2918

36. Fowble B, Solin LJ, Schultz DJ, Goodman RL. Ten year results of conservative surgery and irradiation for stage I and II breast cancer. Int J Radiat Oncol Biol Phys 1991; 21:269-277

37. Arenas M, Sabater S, Hernandez V, et al. Cosmetic outcome of breast conservative treatment for early stage breast cancer. Clin Transl Oncol 2006:8:334-338

38. Goldhirsch A, Glick JH, Gelber RD, Coates AS, Thurlimann B, Senn HJ. Meeting highlights: international expert consensus on the primary therapy of early breast cancer 2005. Ann Oncol 2005;16:1569-1583

39. Veronesi U, Marubini E, Mariani L, et al. Radiotherapy after breast conserving surgery in small breast carcinoma: long term results of a randomized trial. Ann Oncol 2001;12:997-1003

40. Hughes KS, Schnaper LA, Berry D, et al. Lumpectomy plus tamoxifen with or without irradiation in women 70 years of age or older with early breast cancer. N Engl J Med 2004; 351:971-977

41. Arthur D. Accelerated partial breast irradiation: a change in treatment paradigm for early stage breast cancer. J Surg Oncol 2003;84:185-191 


\title{
초기 유방암의 유방보존수술과 방사선치료의 장기추적결과
}

\author{
계명대학교 의과대학 동산의료원 방사선종양학교실
}

\section{김 진 희·변 상 준}

목 적: 초기 유방암에서 유방 보존 수술과 방사선치료 후 실패양상과 생존율 및 미용효과를 알아보고자 하였다. 대상 및 방법: 1992년 1월부터 2002년 12월까지 계명대학교 동산의료원에서 유방보존수술과 방사선치료를 받은 초기 유방암환자 154명을 대상으로 하였다. TNM 병기는 1기 90명, Ila기 50명, Ilb기 11명이었다. 모든 환자는 유 방의 부분절제술과 동측 액와림프절 곽청술을 시행하고 방사선치료를 하였다. 유방의 방사선치료는 동측 전체 유 방에 $6 \mathrm{MV}$ 광자선으로 50 54 Gy를 5주에서 6주간에 조사하였고 원발병소에 추가 방사선은 전자선으로 10 16 Gy를 조사하였다. 항암화학요법은 75명에서 방사선치료 전후에 시행하였고 호르몬치료는 92명에서 Tamoxifen을 사용하였다. 추적관찰기간은 13 개월에서 179 개월로 중앙값이 92.5 개월이었다.

결 과: 전체환자의 5년, 10 년 생존율은 $97.3 \%, 94.5 \%$ 이었다. 5년, 10년 무병생존율은 $92.5 \%, 88.9 \%$ 이었고 구제 치료후 5년, 10 년 무병생존율은 $93.9 \%, 90.2 \%$ 이었다. 다변량 분석상 수술 후 방사선치료까지의 기간이 $(\leq 6$ weeks vs. $>6$ weeks, $\mathrm{p}=0.017)$ 무병생존율에 있어서 통계적으로 유의한 예후 인자였다. 주된 실패양상은 원격전 이였고 다발성으로 치료 후 중앙값 55.5 개월에 전이를 하였다. 원격전이의 호발부위는 폐였다. 미용결과는 $80.7 \%$ 에서 좋음에서 매우 좋음으로 나타났다.

결 론: 초기 유방암에서 유방보존수술과 방사선치료는 우수한 생존율과 미용결과를 보인다고 생각된다. 또한 유방 보존수술 후 방사선치료는 가능한 한 빨리, 6주 이내에 시행되는 것이 좋을 것으로 생각된다.

핵심용어: 초기 유방암, 유방보존수술, 방사선치료, 생존율, 실패양상 